\title{
STRATEGI BERSAING DAN PENGUKURAN KINERJA DENGAN PENDEKATAN RESOURCES BASE VIEW PERUSAHAAN KOMPONEN OTOMOTIF INDONESIA
}

\author{
COMPETITIVENESS STRATEGY AND PERFORMANCE MEASUREMENT BY \\ RESOURCES BASE VIEW APPROACH IN INDONESIAN AUTOMOTIVE COMPONENT COMPANY
}

\author{
Purwantoro $^{*}$, , Heny K Daryanto ${ }^{* *}$, dan Setiadi Djohar ${ }^{* * *}$ \\ *) PT Indokarlo Perkasa \\ Jl. Raya Bogor No.507, Cibinong, Bogor 16912 \\ ${ }^{* *}$ Sekolah Bisnis, Institut Pertanian Bogor \\ Jl. Raya Pajajaran, Bogor 16151 \\ ${ }^{* * *}$ Sekolah Tinggi Manajemen PPM \\ Jl. Menteng Raya No. 9-19, DKI Jakarta 10340
}

\begin{abstract}
Indonesia has the highest growth of motor vehicle industry in Southeast Asia. The shifting of central car production has started since 2012 with the initial launch of low cost green car (LCGC). This development was followed by the growth of automotive component industry to support it. To compete in business coverage with high attractiveness industry, strategies and highly capable human resources are required by the company. This research utilized resource-based view in examining the connection between Porter's competitiveness strategy and company's human resource and its performance. This research classified human resource configuration into product-based and process-based, and the companies were categorized into strategic groups. Thus, this research examined the different performances between strategic groups. The relationship between human resource configuration and strategies was analyzed to reveal the differences of human resource and its competence in one strategic group and to examine its connection to the company's performance. The primary finding in this research was the significant differences of performances among strategic groups in which companies in the same group have a distinctive human resource configuration.
\end{abstract}

Keywords: competitiveness strategy, base resource, performance, competitive advantage

\begin{abstract}
Abstrak: Indonesia mempunyai pertumbuhan industri kendaraan bermotor tertingi di Asia Teggara. Pergeseran pusat produksi mobil sudah dimulai sejak tahun 2012 dengan diluncurkannya low cost green car (LCGC). Perkembangan ini diikuti oleh tumbuhnya industri komponen otomotif sebagai pendukungnya. Untuk dapat bersaing dalam lingkungan bisnis dengan industry actractiveness yang masih tinggi diperlukan strategi dan capability sumber daya yang unggul bagi perusahaan. Penelitian ini menggunakan resources base view dalam menganalisis keterkaitan antara strategi bersaing Porter, sumber aya perusahaan dan kinerja. Dalam penelitian ini penulis membagi konfigurasi sumber daya menjadi product based dan processs based. Lalu perusahaan-perusahaan ini dikelompokkan dalam grup strategi dan mengukur perbedaan kinerja antara grup strategi. Hubungan antara konfigurasi sumberdaya dan strategi dianalisis untuk mengetahui perbedaan sumber daya dan distinctive competence dalam satu grup strategi dan menganalisis keterkaitannya dengan kinerja perusahaan.Temuan utama dalam penelitian ini adalah bahwa terdapat perbedaan kinerja yang signifikan diantara grup strategi, perusahaan-perusahan dalam satu grup strategi memiliki perbedaan konfigurasi sumber daya.
\end{abstract}

Kata kunci: strategi bersaing, resources base, kinerja, competitive advantage

\footnotetext{
${ }^{1}$ Alamat Korespondensi:

Email: yunidka@gmail.com
} 


\section{PENDAHULUAN}

Produksi kendaraan bermotor Indonesia mengalami kemajuan yang sangat signifikan, kenaikan produksi ini juga seiring dengan kenaikan kebutuhan pasar domestik yang juga mengalami kenaikan. Tahun 2012 jumlah produksi mobil Indonesia melebihi 1 juta unit, dan terus masih menunjukan kenaikan hingga mencapai 1,2 juta unit pada tahun 2013 (KPMG, 2014). Hal ini merupakan pencapaian tertinggi sepanjang sejarah otomotif Indonesia.

Pertumbuhan ekonomi kelas menengah (midleclass) merupakan pendukung utama dari pertumbuhan GDP Indonesia yang secara tidak langsung menyokong pertumbuhan industri otomotif. Peluncuran Low Cost Green Car (LCGC) merupakan faktor pendukung lain tumbuh pesatnya industri ini. Pemerintah Indonesia berkeinginan agar pada tahun 2025 Indonesia akan menjadi negara basis manufaktur kendaraan bermotor dengan kemampuan produksi dan desain sendiri (KPMG, 2014). Berdasarkan data dari Gabungan Industri Alat Alat Mobil dan Motor (GIAMM) sebanyak 50 perusahaan komponen kendaraan bermotor baru antara lain berasal dari Jepang, Thailand, Malaysia, dan Taiwan berencana membangun pabrik di tanah air (GIAMM, 2016). Dengan kondisi external saat ini, maka persaingan dalam industri komponen di Indonesia menjadi semakin ketat. Positioning strategi bersaing perusahaan akan berpengaruh kepada kinerja perusahaan, dan hal ini tergantung bagaimana masingmasing perusahaan menetapkan aktivitas sumber daya mana yang akan di perkuat dan bagaimana menyusun konfigurasi setiap kegiatan sumber daya secara individual serta menetapkan dan mengkoordinasikan bagaimana seluruh aktivitas sumber daya ini menjadi saling terhubung satu dengan yang lainnya (Frensterseifer, 2009).

Penelitian ini mengacu beberapa penelitian sebelumnya, yaitu Pertama, Jusoh dan Parnell (2007) meneliti hubungan antara strategi bersaing dan kinerja perusahaan untuk perusahaan manufaktur di Malaysia dengan menggunakan variabel pengukuran finansial dan non finansial berdasarkan balanced scorecard. Penelitian ini menemukan bahwa perusahaanperusahaan manufaktur di Malaysia lebih cenderung untuk menerapkan strategi sebagai Innovative Efficient Customer oriented (IEC) yang merupakan kombinasi dari cost leadership dan differentiation, serta perusahaan yang bersaing dengan menerapkan strategi cost leadership. Kedua, Furrer et al. (2008) meneliti hubungan antara sumber daya perusahaan dengan strategi bersaing berdasarkan tipologi strategi bersaing generik Porter, dan kinerja perusahaan dalam konteks industri baru yaitu teknologi pemasaran digital. Dengan menggunakan pengembangan dari 21 competitive method yang dipergunakan oleh Davis pada penelitian sebelumnya. Furrer menghubungkan kelompok strategi dalam industri pemasaran digital kedalam empat kelompok strategi, yaitu product orientation (PO), market orientation (MO), scope, dan conservative cost control. Furrer menghubungkan strategi yang dipilih oleh perusahaan dengan konfigurasi sumber daya yang ada dalam masingmasing prusahaaan dan mengevaluasi konfigurasi yang menyumbangkan kinerja perusahaan yang paling optimal dengan perusahaan lainnya. Ketiga, O'Regan et al. (2011) meneliti hubungan antara penerapan strategi dengan kinerja perusahaan dengan mengambil data dari perusahaan plastik di United Kingdom (UK). Penelitian ini menyimpulkan hasil yang sama dengan penelitian yang di lakukan oleh Dess dan Davis (1984) bahwa tidak ada keterkaitan antara pemilihan dan penerapan strategi generik Porter dengan Return On Asset (ROA) dari perusahaan dalam grup strategi yang terbentuk dalam cluster analysis. Keempat, Ismail et al. (2012) meneliti hubungan antara keunggulan bersaing di perusahaan manufaktur Malaysia. Dengan menggunakan resources based view (RBV), dianalisis keterkaitan antara keunggulan bersaing perusahaan dan kinerja perusahaan. Hasil temuannya menyatakan ada hubungan yang signifikan antara sumber daya perusahaan dengan keunggulan bersaing perusahaan. Kelima, Pearson et al. (2015) melakukan penelitian di 46 perusahaan penerbangan di Asia dengan analisis berbasis RBV dengan membagi perusahaan-perusahaan penerbangan tersebut kedalam tiga kategori, yaitu network air line, low cost airline yang merupakan anak cabang dari network airline dan low cost carrier. Penelitian ini menganalisis sumber daya intangible dengan menggunakan kerangka kerja valuable, rare, inimmitability, organization (VRIO). Dalam penelitian ini ditemukan bahwa untuk perusahaan penerbangan network airline lebih mengandalkan reputasi produk dan pelayanan sebagai sumber daya intangible utama dalam keunggulan bersaingnya sementara low cost dari anak cabang network airline dan low cost carrier (LCC) lebih mengandalkan slot sebagai sumber daya penting dalam keunggulan bersaingnya. 
Penelitian ini bertujuan menganalisis hubungan antara pemilihan strategi perusahaan, konfigurasi sumber daya dan kinerja dengan menganalisis pemilihan srategi, menentukan konfigurasi sumber daya, menganalisis ketersediaan distinctive advantage dan membandingkan kinerja perusahaan.

Ruang lingkup penelitian ini mencakup analisis penerapan strategi perusahaan berbasis competitive method dan variabel strategi, mengidentifikasi konfigurasi sumber daya dan identifikasi distinctive competence dengan kerangka VRIO. Penelitian ini berfokus kepada menganalisis luaran (outcome) dari keputusan top manajemen dalam menentukan orientasi strategi bersaing perusahan.

\section{METODE}

Penelitian ini dilakukan di perusahaan-perusahaan manufaktur komponen kendaraan di Indonesia. Data primer diperoleh melalui semistructured questioner dengan menggunakan likert scale untuk mengukur sikap pimpinan perusahaan dalam menilai competitive method untuk menentukan intended strategy. Likert scale digunakan untuk mengukur sikap, pendapat, dan persepsi seseorang atau sekelompok orang tentang fenomena sosial (Sugiyono, 2010). Data sekunder didapat dari arsip perusahaan serta beberapa literatur dan referensi dari luar perusahaan. Enam perusahaan dipilih sebagai obyek penelitian. Responden adalah executive in charge perusahaan yang dipilih dengan menggunakan teknik purposive sampling.

Identifikasi konfigurasi sumber daya masing-masing perusahaan berbeda tergantung bagaimana mereka menjalankan bisnisnya. Penulis membagi konfigurasi sumber daya menjadi dua, yaitu product based dan process based. Ada tiga kondisi konfigurasi sumber daya disesuaikan dengan konfigurasi manufaktur yang di tetapkan perusahaan, yaitu 1) Perusahaan manufaktur process based: perusahaan yang dari awal bergerak di bidang manufaktur komponen dan dengan kemampuan sendiri mengembangkan kemampuan sumber dayanya sehingga terbentuk koordinasi dan sistim kerja antar sumber daya yang mendukung process based; 2) Perusahaan manufaktur product based: perusahaan ini mempunyai sumber daya yang unggul dibidang teknologi yang di dapat dari partner atau induk perusahaan joint venture. Sumber daya pada perusahaan ini berorientasi kepada produk sehingga memiliki ciri khas dalam berproduksi yaitu menggunakan mesin-mesin khusus dengan kapasitas besar; 3) Perusahaan manufaktur yang menggunakan kedua strategi manufaktur yaitu process based dan product based. Perusahaan-perusahaan ini adalah perusahaan yang pada awalnya adalah process based tetapi mulai berusaha untuk pindah ke product based.

Analisis konfigurasi sumber daya dengan menggunakan enam skenario utama pertanyaan dalam kuisioner sehingga responden dapat memberikan respon sesuai dengan kondisi perusahaan sebagai berikut: perusahaan mengembangkan teknologi manufaktur yang dikembangkan sendiri berdasarkan pengalaman perusahaan selama bertahun-tahun; perusahaan memiliki teknologi manufaktur yang sudah dikembangkan sebelumnya oleh principal/partner; perusahaan memulai sendiri teknologi manufakturnya dari pengembangan kemampuan enginering dari induk perusahaan; memproduksi satu kategori produk yang standar dengan mesin khusus dengan volume produksi yang besar; memproduksi berbagai kategori produk dengan mesin yang disesuaikan dengan kebutuhan produk dan volume sesuai permintaan pelanggan; memproduksi produk standar dan juga produk lain sesuai permintaan pelanggan dengan volume sesuai perrmintaan pelanggan.

Dari keenam perusahaan terdapat 2 perusahaan menerapkan konfigurasi process based, 4 perusahaan menerapkan product based dan tidak ada perusahaan menerapkan kedua konfigurasi manufaktur.

Sumber daya organisasi dianalisis dengan menggunakan kerangka kerja valuable, rare. inimmitability, organization (VRIO) untuk menentukan sumber daya unggulan dari masing-masing perusahaan. Analisis ini mengacu kepada penelitian Pearson et al. (2015) tanpa menggunakan interval rating. Sumber daya dan competensi yang dapat memenuhi kriteria VRIO dianggap sebagai distinctive competence dari perusahaan. Masing-masing perusahaan akan memiliki jenis dan jumlah sumber daya unggulan yang berbedabeda.

Dimensi strategi bisnis dalam penelitian ini mengacu kepada strategi generik Porter. Dalam tipologi strategi generik Porter (1985) membagi strategi menjadi tiga strategi generik yaitu: cost leadership, differentiation dan fokus. Analsis pemilihan dan penerapan strategi dilakukan berdasarkan kuesioner dan interview 
berdasarkan 21 competitive method Dess dan Davis (1984) yang dipakai juga oleh Jusoh dan Parnell (2007) dan Furrer et al. (2008). Dalam penelitian ini dipilih empat variabel untuk masing masing strategi sesuai dengan kriteria yang diusulkan oleh panel ahli yang dipakai dalam penelitian Dess dan Davis (1984) sebagai berikut: cost leadership (cost leadership): Operating efficiency, competitive pricing, procurement of raw materials dan innovation in manufacturing process. Selanjutnya, deferensiasi (Differentiation): new product development, brand identification, innovation in marketing technique and methods and advertising. Fokus (focus): customer service, brand identification, serving special geographic market dan capability to manufacture specialty product.

Dari data yang didapat melalui kuisioner dengan menggunakan 21 pertanyaan dapat dilakukan pendekatan sejauh mana perusahaan lebih menekankan tindakan strategisnya dari 21 pilihan yang ada dengan cara membandingkan skor tertinggi dari responden dan menetapkan dimensi strategi yang sesuai dengan kriteria panel Dess dan Davis (1984).

Analisis faktor untuk masing masing kelompok strategi untuk melihat factor loading dari masingmasing kelompok strategi. Analisis ini dimaksudkan untuk mengetahui secara agregat dari enam perusahaan yang menjadi responden mengenai strategi bersaing yang di pilih oleh perusahaan. Setelah itu masing masing perusahaan akan di kelompokkan kedalam grup strategi berdasarkan kepada kriteria penelitian Dess dan Davis (1984) dengan membandingkan grup strategi dengan competitive method dan strategi dengan strategic variable yang diturunkan menggunakan variabel-variabel finansial sepeti dalam penelitian yang dilakukan oleh Hudson (2001).

Kinerja perusahaan diukur dengan menggunakan empat perspektif balance scorecard (BSC) dengan mengukur kinerja perusahaan pada tahun trakhir yaitu: perspetif finansial, perspektif pelanggan, perspetif internal business process dan perspetif learning and growth. Indeks kinerja dihitung dengan menggunakan analisis faktor tanpa rotasi. Faktor-faktor yang akan di analsis meliputi beberapa faktor seperti pada Tabel 1 .

Strategi bersaing yang saat ini dijalankan perusahaan dan dibandingkan dengan kinerja perusahaan dilakukan dengan menggunakan ANOVA untuk mengetahui ada atau tidaknya perbedaan yang signifikan antara pemilihan strategi bersaing di antara grup strategi perusahaan dan kinerja perusahaan.

Analisis pemilihan strategi bersaing dan konfigurasi sumber daya perusahaan dengan menggunakan ANOVA untuk mengetahui apakah dalam satu grup strategi perusahaan-perusahaan ini memiliki konfigurasi sumber daya yang berbeda.

Gap analysis dilakukan untuk menganalis dan membandingkan antara strategi dan kinerja aktual dan kinerja strategi optimal. Perbedaan kinerja antara konfigurasi sumber daya dianalisis dengan menghubungkan kinerja dan ketersediaan sumber daya unggulan dari masing masing perusahaan. Konfigurasi sumber daya dianalisis dengan menggunakan kerangka VRIO dimana tidak dilakukan multivariate analysis untuk menghindari generalisasi konfigurasi sumber daya (Robinson, 2008)

\section{HASIL}

Analisis grup strategi dimaksudkan untuk mengetahui secara total bagaimana strategic action dari pimpinan perusahaan dalam memahami pilihan strategi yang dijalankan oleh perusahaan-perusahaan yang menjadi responden. Dari 21 competitive method yang diturunkan oleh Dess dan Davis (1984) ditetapkan 11 yang dianggap paling penting oleh para ahli strategi yang dijadikan panel dalam penelitian Dess dan Davis (1984). Berdasarkan 11 competitive method dilakukan faktor analisis untuk menentukan faktor yang dominan dengan analisis principle component seperti pada Tabel 2. Dengan mempertimbangkan Eigen value yang lebih besar dari 1.0 dan dari Scree plot dari hasil analisis principal component ditentukan jumlah faktor dengan Eigen value yang lebih dari 1,0 sehingga terdapat 3 faktor dengan akumulasi varian mencapai $80 \%$ dari total varian.

Diskripsi statistik data memperlihatkan tingkat kepentingan dari masing masing variabel competitive method perusahaan berdasarkan kepada koefisien faktor dari masing-masing variabel. Dengan mengacu kepada score factor yang masih bisa untuk melakukan exploratory analysis, yaitu 0,3 (Kim dan Mueller, 1978) data koefisien memperlihatkan bahwa faktor 1 mendapatkan loading koefisien yang paling banyak, yaitu 6 dari 12 variabel yang ada, faktor 2 loading 5 dari 12 faktor dan faktor 3 hanya 2 dari 12 faktor. Namun, 
dalam analisis faktor ini deskripsi statistik hasil analisis tidak dapat membedakan dengan jelas bagaimana memisahkan metode bersaing ini menjadi satu strategi bersaing generik dan tidak menunjukkan secara tegas bagaimana strategi bersaing ini terbentuk walaupun secara umum dapat ditarik kesimpulan bahwa ada dua faktor yang dominan dari analsis variabel.

Dengan menggunakan compettitive method dari hasil panel pada penelitian Dess dan Davis (1984) dan dengan menggunakan paired t-test maka perusahaan perusahaan ini dapat di kelompokkan dalam strategi generik dalam Tabel 3.

Analisis paired-t memperlihatkan bahwa jawaban kuesioner responden memperlihatkan perusahaan cenderung untuk menerapkan strategi bersaing differentiation. Berdasarkan penelitian yang dilakukan oleh Hudson (2001) dengan mengadopsi variabel strategi Porter (1985) seperti ditunjukkan dalam Tabel
4 dimana strategic action dapat dicerminkan dari parameter finansial perusahaan, yaitu sebagai berikut:

1) Gross profit margin untuk membedakan perusahaan dalam menentukan keuntungan dan membebankan investasi dan semua biaya kedalam produknya.

2) Asset efficiency merupakan parameter strategic action yang membedakan perusahaan yang menerapkan strategi bersaing differensiasi cenderung untuk mempunyai asset efficiency yang rendah. Sebaliknya, cost leadership sangat mengandalkan perputaran cash yang cepat untuk operasional sehingga asset efficiency menjadi tinggi.

3) Capital intensity mengindikasikan penggunaan aset perusahaan, pada perusahaan yang menerapkan strategi bersaing generik cost leadership, perusahaan-perusahaan ini akan menggunakan mesin-mesin yang khusus dan memproduksi dengan skala besar sehingga nilai aset yang di pergunakan untuk tiap produknya menjadi besar.

Tabel 1. Pengukuran kinerja

\begin{tabular}{lccl}
\hline Variabel & Faktor1 & Faktor 2 & Communality \\
\hline Finansial & $-0,952$ & 0,239 & 0,963 \\
Customer & 0,880 & $-0,434$ & 0,963 \\
Internal business & $-0,856$ & $-0,240$ & 0,790 \\
Learning and growth & $-0,795$ & $-0,508$ & 0,891 \\
Variance & 3,046 & 0,561 & 3,607 \\
\% variance & 0,761 & 0,140 & 0,902 \\
\hline
\end{tabular}

Tabel 2. Principal component analysis

\begin{tabular}{lccc}
\hline Variabel & Faktor 1 & Faktor 2 & Faktor 3 \\
\hline Product development & 0,00 & $-0,52$ & 0,27 \\
Pelayanan pelanggan & 0,42 & 0,07 & $-0,09$ \\
Efisiensi operasional & 0,39 & 0,18 & 0,13 \\
Harga kompetitif & 0,40 & $-0,12$ & 0,19 \\
Brand identification & $-0,16$ & $-0,51$ & 0,03 \\
Inovasi teknik pemasaran dan metode pemasaran & $-0,02$ & $-0,30$ & $-0,60$ \\
Pengadan bahan baku & 0,25 & $-0,44$ & $-0,06$ \\
Melayani pasar dalam area tertentu & $-0,32$ & 0,31 & 0,18 \\
Kemampuan produksi produk tertentu & 0,01 & $-0,14$ & 0,68 \\
lklan & $-0,42$ & $-0,07$ & 0,09 \\
Inovasi dalam proses manufaktur & 0,39 & 0,10 & 0,01 \\
Elgen Value & 5,55 & 3,15 & 2,02 \\
Percentage of variance & $51 \%$ & $29 \%$ & $18 \%$ \\
\hline
\end{tabular}


Tabel 3. Pemilihan strategi bersaing generik

\begin{tabular}{clcccccc}
\hline \multicolumn{1}{c}{ Strategi } & & ACO1 & AC02 & AC03 & AC04 & AC05 & AC06 \\
\hline Differentiation & Mean Dif & $-0,027$ & $-0,122$ & 0,449 & $-0,027$ & 0,306 & $-0,075$ \\
& P-Value & 0,943 & 0,572 & 0,179 & 0,943 & 0,494 & 0,802 \\
Cost leadership & Mean Dif & 0,741 & 0,646 & I $; 21 \mathrm{~S}$ & 0,741 & 1,075 & 0,694 \\
& P-Value & 0.024 & 0.047 & 0.001 & 0.024 & 0.009 & 0.040 \\
& & DF & DF & DF & DF & DF & DF \\
\hline
\end{tabular}

4) Productivity adalah variabel strategic action yang mengukur tingkat produktifitas karyawan perusahaan. Strategi cost leadership dicirikan produktivitas lebih tinggi dengan kapasitas produksi yang besar.

Secara ringkas variabel-variabel tersebut di simpulkan dalam Tabel 4 yang di modifikasi dari tabel yang di buat dalam penelitian Hudson (2001). Tabel 5 ini dipergunakan oleh Hudson untuk menentukan strategi yang di pilih oleh perusahaan komponen otomotif di Amerika Serikat dan ditinjau dari variabel strateginya.

Tabel 4. Variabel strategi berdasarkan Hudson

\begin{tabular}{ll}
\multicolumn{1}{c}{ Variabel Strategi } & \multicolumn{1}{c}{ Rumusan } \\
\hline Gross Profit Margin & Gross profit/net sales \\
Efficiency & Account receivable/sales \\
Productivity & Sales/Jumlah karyawan \\
Capital Intensity & Plant \& equipment/sales \\
\hline
\end{tabular}

Tabel 5 ini dipergunakan oleh Hudson untuk menentukan strategi yang di pilih oleh perusahaan komponen otomotif di Amerika Serikat dan ditinjau dari variabel strateginya. Variabel-variabel ini diturunkan dari penelitian sebelumnya oleh Helm et al. (1992) dan Lawless et al.(1988).

Metode analisis ini dinilai lebih robust (Hudson, 2001) karena dapat menghindari monomethod bias atau deskripsi strategi yang bersifat self reported. Analisis kinerja finansial dari data sekunder didapatan hasil seperti pada Tabel 6 yang berbeda dengan pengelompokan strategi pada bagian terdahulu, yaitu dengan 2 perusahaan menerapkan strategi cost leadership dan 4 perusahaan lainnya menerapkan strategi bersaing differentiaiton. Pada analisis ini ada 2 perusahaan yang menjadi catatan bahwa tidak dipenuhinya variabel productivity dengan gross profit perusahaan yang tidak tergolong tinggi sehingga digolongkan kedalam kategori strategi differensiasi dengan catatan bahwa bukan karena perusahaaan ini dapat meminta harga lebih tinggi ke customer tetapi lebih karena productivity yang rendah.
Hasil analisis ANOVA pada Tabel 7 menunjukkan adanya perbedaan indeks kinerja total yang signifikan dengan p-value 0,032 diantara perusahaan-perusahaan yang memilih strategi bersaing cost leadership dan diferentiation. Indeks kinerja total yang lebih baik ditunjukkan oleh strategi bersaing differentiation .

Perbedaan signifikan terdapat pada kinerja perspektif finansial dengan p-value 0,04 dan pada perspektif customer dengan p-value 0,016. Hal ini konsisten dengan pendapat Porter (1996) bahwa strategi terkait secara langsung dengan kinerja finansial perusahaan terutama pada keuntungan perusahaan. Pada kelompok strategi cost leadership tidak memperlihatkan varian yang besar dalam kinerja, tetapi untuk kelompok differensiasi terdapat variasi yang besar pada kinerjanya dengan standar deviasi 0,0913 seperti ditunjukkan pada Tabel 8. Merupakan temuan yang menarik bahwa terdapat varian kinerja dalam satu grup strategi, pada bagian berikutnya akan dianalisis lebih lanjut bagaimana perbedaan kinerja dalam satu kelompok atau grup strategi.

\section{Perbedaan Konfigurasi Sumber daya dalam Grup Strategi}

Analisis konfigurasi sumber daya dalam satu grup strategi dilakukan dengan menggunakan indeks kinerja. Perbedaan kinerja yang ditunjukkan dalam satu grup strategi pada Tabel 9, mengindikasikan adanya perbedaan konfigurasi sumber daya dalam pada masing-masing perusahaan.

Perbedaan konfigurasi sumber daya ini dianalisis dengan menggunakan ANOVA untuk menentukan varian antar grup dan varian dalam grup. Dengan menggunakan kuesioner 6 skenario konfigurasi sumber daya dikombinasikan dengan indeks total kinerja perusahaan didapatkan hasil yang ditunjukkan pada Tabel 10. 
Tabel 5. Kriteria variabel strategi generik

\begin{tabular}{lcc}
\hline Variabel strategi & Strategi generik & Cost leadership \\
\hline Gross profit margin & Low & High \\
Efficiency & High & Low \\
Productivity & High & Low \\
Capital intensity & High & Low \\
\hline
\end{tabular}

Keterangan: untuk efficiency semakin tinggi perputaran cash semakin kecil rasionya

Tabel 6. Strategi bersaing perusahaan berdasaran variabel strategi

\begin{tabular}{lccccccccc}
\hline Sariabel strategi & Strategi generik & \multirow{2}{*}{ AC01 } & AC02 & AC03 & AC04 & AC05 & AC06 & Mean & Std.Dev \\
\hline Gross profit margin & 0,07 & 0,048 & 0,13 & 0,20 & 0,13 & 0,07 & 0,11 & 0,05 \\
Efficiency & 1,43 & 0,01 & 1,16 & 0,35 & 0,27 & 0,52 & 0,62 & 0,50 \\
Productivity & 0,73 & $-0,15$ & 2,27 & 0,83 & 1,40 & 3,02 & 1,40 & 0,98 \\
Capital intensity & 0,72 & 88,30 & 0,76 & 3,13 & 4,75 & 2,25 & 16,65 & 32,07 \\
\hline \multicolumn{1}{c}{ Strategi } & DP* & DP* & DF & DF & CL & CL & &
\end{tabular}

Keterangan: DF* (tidak memenuhi kriteria CL); AC01-AC06 (kode untuk perusahaan sample); DF (Differentiation); CL (Cost leadership).

Tabel 7. Parameter perbandingan kinerja

\begin{tabular}{lcccccc}
\hline Kinerja Finansial & Mean Square & DF & Error Mean Square & DF & F-Statistic & P-value \\
\hline Finansial & 0,063080 & 1 & 0,001680 & 4 & 37,52 & 0,004 \\
Customer & 0,010208 & 1 & 0,000631 & 4 & 16,17 & 0,016 \\
Internal business process & 0,001210 & 1 & 0,001210 & 4 & 4,65 & 0,097 \\
Learning \& growth & 0,000408 & 1 & 0,000531 & 4 & 0,77 & 0,430 \\
Total & 0,070530 & 1 & 0,026800 & 4 & 10,53 & 0,032 \\
\hline
\end{tabular}

Tabel 8. Perbedaan kinerja perusahaan antar grup strategi

\begin{tabular}{lcc}
\hline Kinerja & Cost leadership & Differentiation \\
\hline Jumlah perusahaan & 2 & 4 \\
Means & 0,7400 & 0,9700 \\
Standar deviasi & 0,0424 & 0,0913 \\
\hline
\end{tabular}

Tabel 9. Kinerja dan konfigurasi sumberdaya dalam grup strategi

\begin{tabular}{lcccc}
\hline \multirow{2}{*}{ Grup strategi } & Konfigurasi sumber daya & \multicolumn{2}{c}{ Product based $(\mathrm{n}=4)$} & \multicolumn{3}{c}{ Product based $(\mathrm{n}=2)$} \\
\cline { 2 - 5 } Differentiation & Mean & Std. Dev & Mean & Std. Dev \\
Cost leadership & 1,035 & 0,0636 & 0,905 & 0,064 \\
\end{tabular}

*) tidak ada kombinasi strategi cost leadership dan process based

Tabel 10. Analisa ANOVA kombinasi strategi dan konfigurasi sumberdaya

\begin{tabular}{lccccc}
\hline Source & Df & SS & MS & F & P \\
\hline StratRes & 2 & 0,08743 & 0,04372 & 13,25 & 0,032 \\
Error & 3 & 0,00990 & 0,00330 & & \\
Total & 5 & 0,09733 & & & \\
S $=0,05745$ & & R-Sq $=89,83 \%$ & & R-Sq(Adj) $=83,05 \%$ & \\
\hline
\end{tabular}

Keterangan: $\mathrm{DF}=$ degree of freedom, $\mathrm{SS}=$ sum square, $\mathrm{MS}=$ mean square 
Hasil ANOVA didapatkan nilai $F=13,25$ yang berarti bahwa variasi antar grup konfigurasi sumber daya besar dan variasi di dalam grup kecil. Masingmasing kombinasi strategi dan konfigurasi sumber daya menunjukkan perbedaan yang signifikan, hal ini didukung dengan nilai p-value 0,032. Dapat disimpulkan bahwa dalam satu grup strategi dengan terdapat perbedaan konfigurasi sumber daya berakibat kepada perbedaan kinerja yang signifikan. Sejalan dengan pendapat Collis dan Montgomery (2008) bahwa tidak ada dua perusahaan yang mempunyai kesamaan karena tidak ada dua perusahaan yang dapat memiliki pengalaman bisnis yang sama dan membangun aset dan keahlian yang sama demikian juga bentuk organisasi akan berbeda.

\section{Pengukuran Kinerja}

Sebagaimana telah dijelaskan di bagian awal penelitian ini bahwa kinerja perusahaan adalah fungsi dari konfigurasi sumber daya dan perbedaan antara strategi aktual dan strategi yang optimal dari masing-masing konfigurasi sumber dayanya (Furrer, 2008). Barney (1984) dan Porter (1985) telah menjelaskan bahwa strategi dan sumber daya berhubungan langsung dengan kinerja finansial (economic rents). Untuk memberikan pemahaman yang lebih terperinci mengenai kinerja masing-masing perusahaan maka analisis lebih lanjut dilakukan pada variabel-variabel finansial seperti pada Tabel 11. Variabel finansial yang dipakai disini berdasarkan kepada penelitian Hudson (2008).

Berdasarkan Tabel 11, variabel finansial perusahaanperusahan dapat dikelompokkan menjadi 3 kelompok variabel, yaitu variabel profitability (gross profit margin (GPM) dan trading profit margin (TPM)); variabel efektivitas sistem operasional (productivity dan efficiency); dan variabel kinerja aset (capital intensity dan ROA).

Terdapat dua perusahaan (AC05 dan AC06) yang menjalankan strategi bersaing generik cost leadership yang mempunyai variabel profitabilitas yang lebih rendah dibandingkan dengan differensiasi. Cost leader akan memaksimalkan skala ekonomi untuk mendapatkan harga jual yang competitive tetapi dengan skala ekonomi yang memadai perusahaan akan mendapatkan return yang besar. Perusahaan dengan strategi bersaing cost leadership memiliki efisiensi operasional yang tinggi yang tercermin dari produktivitas yang tinggi Jones dan Butler (1988).
Demikian juga dengan penggunaan asset perusahaan ini akan menggunakan aset dengan efisien, memutar cash dengan lebih efisien dengan memperpendek operating cycle. Perusahaan menjalankan strategi bersaing cost leadership karena memiliki capability untuk beroperasi secara efisien yang melingkupi efisiensi operasional, efisiensi modal (capital), efisiensi plan and equipment. Jika dilihat dari latar belakang perusahaan yang menerapkan strategi cost leadership, perusahaanperusahaan ini adalah perusahaan joint venture dimana terdapat perusahaan partner asing.

AC03 dan AC04 adalah perusahaan yang menjalankan strategi generik differentiation, dengan tingkat keuntungan yang lebih tinggi dari cost leader karena perusahaan ini mampu untuk menambah nilai (value), bagi produk maupun proses (Mintzberg, 1988) melalui differentiation yang dilakukan oleh perusahaan. Dalam industri komponen otomotif differentiation tidak harus selalu melekat kepada produk, customer dapat menghargai value perusahaan dari reputasi perusahaan terutama terkait dengan teknologi yang ditawarkan kepada pelanggannya. Teknologi ini bisa teknologi yang melekat pada produk maupun teknologi yang melekat pada mesin produksi yang dipergunakan sebagai jaminan kualitas produknya. Seperti yang terjadi pada perusahaan cost leader, perusahaan dengan strategi differentiation ini jika dilihat dari latar belakangnya juga merupakan perusahaan joint venture, dan ada partner asing yang mendukung sumber daya terutama teknologi.

Kelompok ketiga adalah perusahaan dengan margin penjualan yang tidak tinggi, produktifitas rendah (AC01 dan AC02). Produktifitas pada kelompok perusahaan ini merupakan yang terendah dari 6 perusahaan yang diteliti dengan return on asset juga terendah. Dari latar belakang perusahaan dapat dilihat bahwa perusahan ini adalah perusahaan-perusahaan mandiri tanpa ada dukungan partner dalam berbisnis. Seluruh sumber daya dikelola perusahaan secara mandiri dengan mengandalkan pengalaman.

Analisis sumber daya dengan menggunakan kerangka kerja VRIO, menemukan bahwa perusahan-perusahaan yang memiliki partner asing menunjukkan lebih banyak memiliki sumber daya unggulan dibandingkan dengan perusahaan yang tidak memiliki partner. Keunggulan bersaing yang dimiliki perusahaan, bisa didapat dari berbagai cara, penguasaan akan sumber daya yang bernilai (valuable) yang dapat membuat perusahaan 
bisa melakukan aktifitas yang lebih baik dari pesaingnya (Collis dan Montgomery, 2008). Perusahaan-perusahaan ini (AC03, AC04, AC05, AC06) seluruhnya memiliki sumber daya intanggible yang mendukung bisnisnya, yaitu reputasi dan merek dagang (brand) mereka di industri komponen otomotif .

Pada analisis ini pada Tabel 12 terlihat korelasi yang signifikan antara penguasaan sumber daya unggulan dengan kinerja ROA dan operating margin peremployee dengan p-value 0,049 dan 0,043. Keberadaan partner dominan dalam membangun capability perusahaan.

\section{Implikasi Manajerial}

Analisis grup strategi terdapat perbedaan kinerja yang signifikan diantara grup strategi. Perbedaan ini terutama ada pada variabel finansial dimana perusahaanperusahaan yang menerapkan strategi bersaing generik differentiation memperlihatkan kinerja yang lebih baik dari cost leadership. Temuan yang menarik dalam penelitian ini adalah terdapat dua perusahaan (AC01 dan AC02) dalam kelompok strategi differentiation yang mempunyai variabel finansial lebih rendah dari cost leadersip. Dengan pemetaan Hudson (2001) perusahaan ini masuk ke dalam kategori "stuck in the midle" sebagaimana dijelaskan Porter.

Tabel 11. Kinerja finansial perusahaan

\begin{tabular}{|c|c|c|c|c|c|c|c|c|}
\hline $\begin{array}{ll}\text { Variabel strategi } & \text { Strategi generik }\end{array}$ & $\mathrm{AC} 01$ & $\mathrm{AC} 02$ & $\mathrm{AC} 03$ & $\mathrm{AC} 04$ & $\mathrm{AC} 05$ & $\mathrm{AC} 06$ & Mean & Std.Dev \\
\hline Gross profit margin & 0,07 & 0,048 & 0,13 & 0,20 & 0,13 & 0,07 & 0,11 & 0,05 \\
\hline Effeciency & 1,43 & 0,01 & 1,16 & 0,35 & 0,27 & 0,52 & 0,62 & 0,50 \\
\hline Productivity & 0,73 & 0,15 & 2,27 & 0,83 & 1,40 & 3,02 & 1,40 & 0,98 \\
\hline Capital intensity & 0,72 & 88,30 & 0,76 & 3,13 & 4,75 & 2,25 & 16,65 & 32,07 \\
\hline Trading profit margin & 0,01 & $-1,95$ & 0,06 & 0,11 & 0,02 & 0,02 & $-0,29$ & 0,74 \\
\hline ROA & 0,01 & $-0,12$ & 0,10 & 0,10 & 0,03 & 0,04 & 0,03 & 0,07 \\
\hline
\end{tabular}

Tabel 12. Analisis korelasi distinctive competence dan kinerja finansial perusahaan

\begin{tabular}{|c|c|c|c|c|c|c|c|c|c|}
\hline & & $\begin{array}{l}\text { Strategy } \\
\text { rescource }\end{array}$ & $\begin{array}{l}\text { Distictive } \\
\text { competence }\end{array}$ & GMP & $\begin{array}{l}\text { Asset } \\
\text { effeciency }\end{array}$ & Productivity & $\begin{array}{l}\text { Capital } \\
\text { intensity }\end{array}$ & $\mathrm{ROA}$ & OP/MP \\
\hline \multirow{2}{*}{$\begin{array}{l}\text { Strategy } \\
\text { rescource }\end{array}$} & Coeficient & 1,000 & - & - & - & - & - & - & - \\
\hline & P-value & - & - & - & - & - & - & - & - \\
\hline \multirow{2}{*}{$\begin{array}{l}\text { Distictive } \\
\text { competence }\end{array}$} & Coeficient & 0,682 & 1,000 & - & - & - & - & - & - \\
\hline & P-value & 0,135 & - & - & - & - & - & - & - \\
\hline \multirow[t]{2}{*}{$G M P$} & Coeficient & 0,305 & 0,632 & 1,000 & - & - & - & - & - \\
\hline & P-value & 0,556 & 0,178 & - & - & - & - & - & \\
\hline \multirow{2}{*}{$\begin{array}{l}\text { Asset } \\
\text { effeciency }\end{array}$} & Coeficient & $-0,263$ & $-0,012$ & $-0,074$ & 1,000 & - & - & - & - \\
\hline & P-value & 0,614 & 0,982 & 0,889 & - & - & - & - & - \\
\hline \multirow[t]{2}{*}{ Productivity } & Coeficient & 0,741 & 0,729 & 0,011 & 0,230 & 1,000 & - & - & - \\
\hline & P-value & 0,092 & 0,100 & 0,983 & 0,662 & - & - & - & - \\
\hline \multirow{2}{*}{$\begin{array}{l}\text { Capital } \\
\text { intensity }\end{array}$} & Coeficient & 0,696 & 0,127 & 0,397 & $-0,909$ & $-0,127$ & 1,000 & - & - \\
\hline & P-value & 0,191 & 0,888 & 0,508 & $\mathbf{0 , 0 3 3}$ & 0,838 & - & - & - \\
\hline \multirow[t]{2}{*}{ ROA } & Coeficient & 0,497 & 0,813 & 0,754 & 0,417 & 0,548 & $-0,077$ & 1,000 & - \\
\hline & P-value & 0,315 & 0,049 & 0,083 & 0,410 & 0,260 & 0,902 & - & - \\
\hline \multirow[t]{2}{*}{ OP/MP } & Coeficient & 0,528 & 0,825 & 0,670 & 0,459 & 0,647 & $-0,195$ & 0,981 & 1,000 \\
\hline & P-value & 0,282 & 0,043 & 0,145 & 0,359 & 0,165 & 0,754 & 0,001 & - \\
\hline
\end{tabular}

$\mathrm{OP} / \mathrm{MP}$ adalah operating profit per man power untuk mengukur produktivitas manufaktur 
Perusahaan-perusahaan ini tidak memiliki daya saing baik dari sisi cost karena tidak produktif dan tidak dapat bersaing dengan differentiation karena tidak mampu menambah nilai (value) dan menjual dengan harga lebih tinggi. Untuk memetakan posisi strategi perusahaan, Harada (2014) telah memperkenalkan konsep dynamic strategy dalam penelitiannya dengan menggunakan quality sebagai bentuk dari differensiasi produk dan cost advantage sama seperti tipologi Porter (1985). Peneliti mengkombinasikannya kedua metode pemetaan ke dalam satu kerangka (Gambar 1) untuk memberikan gambaran dan pemahaman posisi strategi perusahaan-perusahaan yang di teliti. Terdapat satuperusahaan (AC05) memiliki productivity yang tinggi dengan GPM yang lebih rendah dari perusahan lainnya, ini adalah ciri dari perusahan yang menerapkan strategi bersaing cost leadership.

Meskipun Porter (1985), sudah memberikan argumentasinya bahwa kedua strategi generik cost leadership dan differentiation tidak kompatibel untuk diterapkan secara simultan oleh satu perusahaan, tetapi banyak ahli strategi seperti Hill (1988) yang meneliti bahwa kedua strategi tersebut kompatibel dan dapat diterapkan secara simultan. Temuan penelitian ini ada satu perusahaan yang mempunyai variabel kinerja yang mendekati pada penerapan strategi generik cost leadership dan differentiation secara simultan. Thompson dan Stricland (1995) menyebutnya dengan hybrid strategy. Trade off antara cost dan value dapat di hilangkan dengan adanya inovasi baik produk maupun proses (Harada, 2014).

Perusahaan harus mengidentifikasi perusahaan benchmark sebagai acuan dan melakukan penyesuaian terhadap strategi mereka untuk mendekati posisi strategi perusahaan yang dijadikan acuan (Fiegenbaum et al. 1996). Dalam kaitannya dengan penyesuaian sumber daya dan strategi perusahaan dapat meningkatkan kinerja dengan dua cara (Furrer et al. 2008). Perusahaan dapat menyesuaikan strategi menuju srategi optimal yang menjadi acuan dengan tetap mempertahankan konfigurasi sumber daya yang sudah ada, atau dengan menyesuaikan distinctive competence dari perusahaan agar sesuai dengan strategi lain yang lebih optimal kinerjanya. Pilihan pertana merupakan pergeseran strategi dalam strategy space dan pilihan kedua merupakan pergeseran dalam resouce space (Snow and Hambrick, 1980). Untuk perusahaan yang memiliki banyak dukungan sumber daya akan lebih mudah dalam mengadaptasikan strategi dari pada memodifikasi core competence (Cohen dan Levinthal, 1990).

Implikasi manajerial dari penelitian ini adalah menyarankan agar perusahaan mencari kesesuaian antara konfigurasi sumber daya dengan strategi yang menghasilkan kinerja optimal. Sebagai gambaran bahwa perusahaan tidak disarankan untuk meniru begitu saja strategi dari perusahaan dengan kinerja terbaik tetapi perusahaan tersebut menerapkan konfigurasi sumber daya yang berbeda. Perusahaan harus memahami terlebih dahulu ketersediaan sumber daya dan mengadaptasi ke arah strategi acuan dalam satu konfigurasi sumber daya.

\section{KESIMPULAN DAN SARAN}

\section{Kesimpulan}

Beberapa temuan penting dalam penelitian ini dapat disimpulkan sebagai berikut: Terdapat perbedaan yang signifikan dari kinerja perusahaan dengan penerapan strategi bersaing yang berbeda. Dalam industri komponen otomotif di Indonesia ditemukan bahwa perusahaan yang menerapkan strategi bersaing differentiation menunjukkan kinerja lebih optimal dibandingkan dengan strategi cost leadership. Dalam satu grup strategi yang sama terdapat perbedaan kinerja perusahaan yang signifikan. Dengan menerapkan strategi yang sama tidak selalu menghasilkan kinerja yang sama karena masing-masing perusahaan memiliki perbedaan signifikan dari konfigurasi sumber daya. Perusahan-perusahaan yang memiliki dukungan sumber daya unggulan ini menunjukkan perbedaan kinerja yang signifikan lebih optimal dibanding perusahaan yang tidak didukung oleh sumber daya unggul.

\section{Saran}

Hasil penelitian ini tidak dapat digeneralisasi kepada kondisi insdustri komponen otomotif Indonesia secara keseluruhan karena sampel dari responden terbatas kepada beberapa perusahaan dalam satu grup. Penelitian selanjutnya hendaknya mencakup lingkup perusahaan yang lebih luas dengan jumlah perusahaan yang lebih banyak sehingga bisa lebih mewakili kondisi industri komponen otomotif di Indonesia. 


\section{DAFTAR PUSTAKA}

Barney JB. 1991. Firm resources and sustained competitive advantage. Journal of Managenment 17(1): 99-120. https://doi. org/10.1177/014920639101700108.

Cohen W, Levinthal D. 1990. Absorptive capacity: a new perspective on learning and innovation. Administrative Science Quarterly 35(1):28-52. https://doi.org/10.2307/2393553.

Collis DJ, Montgomery CA 2008. Competing on resources. Harvard Business Review July/ August:1-12.

Dess GG, Davis PS. 1984. Porter's (1980) generic strategies as determinants of strategic group membership and organizational performance. Academy of Management Journal 27(3): 467488.

Fiegenbaum A, Hart S, Schendel D. 1996. Strategic reference point theory. Strategic Management Journal 17(3):219-235. https://doi.org/10.1002/ (SICI)1097-0266(199603)17:3<219::AIDSMJ806>3.0.CO;2-N.

Fensterseifer J E. 2009. Strategic resources and sustainability of competitive advantages in industrial clusters: towards a general analytical framework. Encontro da Anpad Sao Paulo 19(23):2-12.

Furrer O, Sudharsan D, Thomas H, Alexandre MT. 2008. Resource configurations, generic strategies, and firm performance; exploring the parallels between resource-based and competitive strategy theories in a new industry. Journal of Strategy and Management 1(1):15-40. https:// doi.org/10.1108/17554250810909400.

[GIAMM] Gabungan Industri Alat-alat Mobil dan Motor. 2016. Industri komponen otomotif bakal kedatangan 50 pemain baru. http://www.giamm. org. [ 5 Juni 2017]

Hambrick DC. 1980. Operationalizing the concept of business-level strategy in research. Academy of Management Journal 5(27):567-575.

Harada T. 2014. Dynamic strategies and management of focusing devices. Journal of Management and Sustainability 4(2):22-33. https://doi. org/10.5539/jms.v4n2p22.

Hambrick DC. 1983. An empirical typology of mature industrial product environments. Academy of Management Journal 26(2):213-230.

Helms MM, Haynes PJ, Cappel SD. 1992. Competitive strategies and business performance within the retailing industry. International Journal of Retail and Distribution Managment 20(5):3-14. https:// doi.org/10.1108/09590559210018259.

Hill CWL. 1988. Differentiation versus low cost: or differentiation and low cost: a contingency framework. Academy of Management Review 13(3):401-412.https://doi.org/10.5465/ amr.1988.4306957.

Hudson RA. 2001. The search for competitive advantage through simultaneous execution of cost leadership and differentiation strategies: an inveatigation into the impact of multiple strategies on the financial performance of firm in the US automotive componentindustry[disertasi]. Florida: Nova Southeastern University.

Ismail AI, Rose RC, Uli J, abdullah H. 2012. The relationship between organizational resources, capabilities, systems and competitive advantage. Asian Academy of Management Journal 17(1):151-173.

Jones GR, Butler JE. 1988. Costs, revenue, and business-level strategy. Academy of Management Review 13(2):202-213. https://doi.org/10.5465/ amr.1988.4306865.

Jusoh R, Parnell JA. 2007. Competitive strategy and performance measurement in the Malaysian context An exploratory study. Management Decision 46(1):5-31. https://doi. org/10.1108/00251740810846716.

Kim J, Mueler C W. 1978. Factor analysis: Statistical method and practical issues. Beverly Hills. California: Sage University Press. https://doi. org/10.4135/9781412984256.

KPMG. 2014. Indonesia's Automotive Industry: Navigating 2014. http://www.kpmg.com [ 5 Juni 2017].

Lawless, M.W., Bergh, D.D., \& Wilsted, W .D. (1989). Performance variations among strategic group members: An examination of individual firm capability. Journal of Management 15(4):649-661. https://doi. org/10.1177/014920638901500412.

Mintzberg H. 1988. Generic strategies: Toward a comprehensive framework. Advances in Strategic Management 5(1):1-67.

O'Regan N, Kluth C, Parnell J. 2011. The demise of strategic groups as an influence on firm performance: lessons from the UK plastics industry. Strategic Change 20(3):111-126. https://doi.org/10.1002/jsc.889.

Pearson J, Pitfield D, Riley T. 2015. Intangible 
resources of competitive advantage: Analysis of 49 Asian airlines across three business models. Journal of Air Transport Management 47(1):179-189.https://doi.org/10.1016/j. jairtraman.2015.06.002.

Porter ME. 1985. Competitive Advantage: Creating and Sustaining Superior Performance. New York: Free Press.
Robinson S. 2008. Understanding the resource-based view: implications of methodological choice and a new creative context [tesis]. Queensland: Queensland University of Technology.

Sugiyono. 2011. Metode Penelitian Kombinasi(Mived Methods). Bandung: CV Alfabeta.

Thompson A A. and Strickland AJ. 1995. Strategic Management: Concepts and Cases. Homewood: Mc GrawHill/Irwin Press. 